\title{
ПРАВО НА ОСВІТУ У СВІТЛІ ПРАКТИКИ ЄВРОПЕЙСЬКОГО СУДУ З ПРАВ ЛЮДИНИ: НОТАТКИ ДЛЯ НАЦІОНАЛЬНОГО СУДУ ЩОДО ЗАХИСТУ ПРАВ ЛЮДИНИ
}

Біла-Кисельова А. А.

\begin{abstract}
у демократичному суспільстві праву на освіту належить визначальне місце. Право на освіту - це право людини на здобуття обсягу знань та інтелектуального розвитку, навичок і вмінь, професійної орієнтації, які необхідні для нормальної життєдіяльності людини в умовах сучасного суспільства у глобальному масштабі, за викликів сьогодення.

Автор привертає увагу до справи "Campbell i Cosans v. The United Kingdom", у якій зазначається, що відмова держави гарантувати доступ до шкільного закладу може становити порушення права на освіту, а також до рішення в Бельгійській мовній справі (Affaire "relative à certains aspects du régime linguistique de l'enseignement en Belgique" c. Belgique), яким установлено, що право на освіту втратить сенс, якщо воно не передбачатиме для його носія права здобувати освіту мовою або мовами національних меншин. Наведено приклади справ щодо Турецької Республіки в питаннях порушення прав національних меншин.
\end{abstract}

Крім того, у статmі автор зазначає, що у світі зростає тенденція вважати, що діти з обмеженими можливостями мають виховуватись $і$ навчатися разом зі своїми ровесниками (інклюзивна освіта).

Окремо у статmі приділяється увагу навчанню дітей у розрізі етнічного походження, щодо доступу до навчання. Наведені приклади рішень Європейського суду з прав людини, які розкривають сутність зобов'язань держав приділяти особливу увагу потребам дітей ромського походження (допомога інтегруватись до звичайних шкіл і розвинути навички, які полегшили 6 їм життя поміж населенням, яке належить до більшості) тощо.

Автор демонструє як Європейський суд з прав людини для витлумачення понять, які містить стаття 2 Протоколу № 1, у своїй практиці неодноразово спирався на такі міжнародно-правові документи: Загальну декларацію прав людини, Конвенцію про боротьбу з дискримінацією в галузі освіти, Міжнародний пакт про економічні, соціальні і культурні права, Міжнародну конвенцію про ліквідацію всіх форм расової дискримінації, Конвенцію про права дитини, Конвенцію про визнання кваліфікації з вищої освіти в європейському регіоні тощо.
Вивчення практики Європейського суду з прав людини дозволяє зробити висновок, що навчання й освіта передбачають доступ до закладів шкільної освіти; передання знань, інтелектуального розвитку; можливість, завдяки офіційному визнанню завершеного навчання (шляхом отримання диплома) отримати переваги від здобутої освіти, відповідно до чинної в кожній державі нормативно-правової бази. Водночас відсутність громадянства не може визнаватися приводом для відмови в доступі до навчання.

Ключові слова: освіта, інклюзивна освіта, мова, суд, права людини, національні меншини, міжнародні стандарти, ЄСПЛ.

Bila-Kyseleva A. A. The right to education the light of European Court of Human Rights practice: notes for the national court on the protection of human rights

In a democratic society, the right to education is crucial. The right to education is a human right to acquire the amount of knowledge and intellectual development, skills and abilities, professional orientation, which are necessary for normal human life in modern society on a global scale in the challenges of today.

The author draws attention to the case of "Campbell and Cosans v. The United Kingdom", which states that the State's refusal to guarantee access to a school may constitute a violation of the right to education. And to the case in the Belgian language case, where it is established that the right to education will lose its meaning if it does not provide for its holder the right to receive education in the language or languages of national minorities. Examples of cases concerning the Republic of Turkey in matters of violation of the rights of national minorities are given.

In addition, in the article the author notes that in the world there is a growing tendency to believe that children with disabilities should be brought up and learn together with their peers (inclusive education).

Separately, the article pays attention to the education of children in terms of ethnic origin - access to education-differentiated attitude. Examples of ECHR decisions that reveal the essence of the obligation of states to pay special attention to the needs of Roma children (help to

( ) Біла-Кисельова А. А., 2020 
integrate into mainstream schools and develop skills that would make life easier for them among the majority population).

The author demonstrates how the ECHR to interpret the concepts contained in Article 2 of Protocol № 1 in its practice has repeatedly relied on the following international legal instruments: the Universal Declaration of Human Rights, the Convention against Discrimination in Education, the International Covenant on Economic, Social and Cultural Rights, The International Convention on the Elimination of All Forms of Racial Discrimination, the Convention on the Rights of the Child, the Convention on the Recognition of Qualifications concerning Higher Education in the European Region, etc.

The study of the case law of the ECHR allows us to conclude that education and training include access to school education; knowledge transfer and intellectual development; the opportunity, through the official recognition of completed education (by obtaining a diploma) to benefit from education, in accordance with current regulations in each country. At the same time, the lack of citizenship cannot be considered a justified sign for denial of access to education.

It is concluded that national courts should take into account the development of international and European law when considering cases related to violations of the right to education through the already certain consensus on language, education and training.

Key words: education, inclusive education, language, court, human rights, national minorities, international standards, ECHR.

Постановка проблеми та іï актуальність. Право кожного на освіту незалежно від місця перебування визнано в чинних міжнародно-правових актах, зокрема у ст. 13 Міжнародного пакту про економічні, соціальні і культурні права 1966 р., ст. 28 Конвенції про права дитини 1989 р., які $\epsilon$ частиною національного законодавства України.

Метою освіти є всебічний гармонійний розвиток людини як особистості, іï талантів, інтелектуальних і фізичних здібностей, формування цінностей, необхідних для успішної самореалізації в житті.

Право на освіту включає право здобувати освіту впродовж усього життя, право на доступність освіти, право на самостійну та безоплатну (оплатну) освіту.

В Україні мають створюватися рівні умови доступу до освіти. Ніхто не може бути обмежений у праві на здобуття освіти. Право на освіту має гарантуватися незалежно від віку, статі, раси, стану здоров'я, інвалідності, громадянства, національності, політичних, релігійних чи інших переконань, кольору шкіри, місця проживання, мови спілкування, походження, соціального і майнового стану, наявності судимості, а також інших обставин і ознак.

Держава має забезпечувати рівний доступ до освіти особам із соціально вразливих верств населення та створювати умови для здобуття освіти особами з особливими освітніми потребами з урахуванням індивідуальних потреб, можливостей, здібностей та інтересів.

Водночас практика національних судів та міжнародних інституцій постійно фіксує порушення прав людини щодо права на освіту.

Мета статті - аналіз практики Європейського суду з прав людини (далі - ЄСПЛ) щодо забезпечення права на освіту (інклюзивна освіта), доступу до освіти національним меншинам та мови навчання; дослідження міжнародних документів, на які спирається ЄСПЛ у тлумаченні правових норм.

Аналіз останніх досліджень і публікацій. Питанню дослідження права на освіту приділяли увагу науковці Л.М. Невара, П.М. Рабінович, В.Г. Чушенко, Н.Г. Шукліна й інші. Водночас вивчення проблематики захисту права на освіту в міжнародних інституціях і використання досвіду ЄСПЛ національними судами потребує додаткового дослідження. Тому досліджувана тема актуальна.

Виклад основного матеріалу. Право на освіту - це право людини на здобуття обсягу знань та інтелектуального розвитку, навичок і вмінь, професійної орієнтації, які необхідні для нормальної життєдіяльності людини в умовах сучасного суспільства у глобальному масштабі, за викликів сьогодення.

Право на освіту в Україні представлено в Основному законі (ст. 53): повна загальна середня освіта $€$ обов'язковою. Держава забезпечує доступність і безоплатність дошкільної, повної загальної середньої, професійно-технічної, вищої освіти в державних і комунальних навчальних закладах; розвиток дошкільної, повної загальної середньої, позашкільної, професійно-технічної, вищої і післядипломної освіти, різних форм навчання; надання державних стипендій та пільг учням і студентам [1].

Конституційний Суд України в рішенні від 21 листопада 2002 р. № 18-рп/2002 зазначив, що обов'язок створити умови для здобуття повної загальної середньої освіти в державних і комунальних навчальних закладах Конституцією України покладено на державу [2].

Доступ до навчання незалежно від статі, раси, стану здоров'я, інвалідності, громадянства, наці- 
ональності й інших обставин має гарантувати держава.

У п. 2.2 рішення Конституційного Суду України від 12 квітня 2012 р. № 9-рп/2012 зазначено: «<...> рівність та недопустимість дискримінації особи $\epsilon$ не тільки конституційними принципами національної юридичної системи України, а й фундаментальними цінностями світового співтовариства, на чому наголошено в актах міжнародного права з питань захисту прав і свобод людини і громадянина, зокрема в Загальній декларації прав людини 1948 р. (ст. ст. 1, 2, 7), Конвенції про захист прав людини і основоположних свобод 1950 р. (ст. 14) та Протоколі № 12 до Конвенції (ст. 1), Міжнародному пакті про громадянські і політичні права 1966 р. (ст. 26)» [3].

Відповідно до ст. 2 Протоколу 1 до Конвенції про захист прав людини і основоположних свобод «Право на освіту», «нікому не може бути відмовлено у праві на освіту. Держава під час виконання будь-яких функцій, узятих нею на себе в галузі освіти і навчання, поважає право батьків забезпечувати таку освіту і навчання відповідно до їхніх релігійних і світоглядних переконань» [4].

Аналіз практики ЄСПЛ демонструє, що навчання й освіта передбачають доступ до закладів шкільної освіти, які існують у даний час (Affaire "relative à certains aspects du régime linguistique de l'enseignement en Belgique" c. Belgique § 4, с. 31 (Бельгійська мовна справа)); передання знань і інтелектуального розвитку (п. 33: навчання дітей - це цілий процес, за допомогою якого в будь-якому суспільстві дорослі намагаються передати молоді свої переконання, культуру та інші цінності) ("Campbell i Cosans v. The United Kingdom”, 25.02.1982); можливість завдяки офіційному визнанню завершеного навчання отримати переваги від здобутої освіти, відповідно до чинної в кожній державі нормативно-правової бази (Affaire "relative à certains aspects du régime linguistique de l'enseignement en Belgique" c. Belgique, § § 3-5, с. 30-32) [5; 6].

Відповідно до рішень ЄСПЛ, освіта, про яку йдеться, включає: початкову шкільну освіту ("Sulak v. Turkey"), повну середню освіту («Kinp v. Turkey” [ВП], § 278), вищу освіту (“Leyla Șahin v. Turkey" [ВП], § 141; “Mürsel Eren v. Turkey”, $\S 41)$, фахову освіту [7; 8; 9; 10]. Наведені приклади розгляду справ щодо Турецької Республіки у зв'язку з тим, що права меншин у Турецькій Республіці забезпечені за допомогою Лозанського договору (розд. III Договору про захист меншин гарантує немусульманським меншинам Туреч- чини: рівність перед законом; право створювати, контролювати та керувати власними установами, включаючи школи, із правом використання в них власної мови; і зобов'язує Туреччину забезпечувати навчання в початкових школах мовами меншин у містах та районах, де проживає значна частина немусульманських громадян). В Україні права національних менших щодо навчання гарантовано Конституцією України (ст. 53). Водночас проблеми, з якими стикаються національні суди, однакові.

Зрозуміло, що освітній процес має відбуватися мовою, зрозумілою тому, кого навчають.

Хоча ст. 2 Протоколу № 1 не уточнює, якою мовою має забезпечуватись освіта, ЄСПЛ у Бельгійській мовній справі (Affaire "relative à certains aspects du régime linguistique de l'enseignement en Belgique” c. Belgique § 3, с. 31) зазначив: «Право на освіту втратить сенс, якщо воно не передбачатиме для його носія право здобувати освіту мовою або мовами (залежно від ситуації) національних меншин» [5].

У справі “Catan and Others v. Republic of Moldova and Russia", яка стосувалась порушення права на освіту через примусове закриття шкільних закладів унаслідок мовної політики сепаратистських органів влади і через послідовне переслідування після відновлення цих шкіл, вказано: «<...> Немає жодних підстав уважати, що такі заходи мали законну мету. Велика палата підкреслила основоположну важливість початкової і середньої освіти для особистого розвитку і майбутнього успіху дитини. Вона нагадала про право отримувати освіту своєю рідною мовою. Держава, яка на той час здійснювала фактичний контроль над згаданим адміністративним органом, незважаючи на те, що вона ні прямо, ні опосередковано не втручалась у його мовну політику, несе відповідальність за порушення права на освіту» [11].

У процесі вивчення проблематики, з якою стикаються національні суди, щодо права на освіту не можна не згадати питання інклюзивної освіти. У світі поширюється тенденція, за якою діти з обмеженими можливостями мають виховуватися разом зі своїми ровесниками. Проте, як вказав ЄСПЛ, такий підхід не може застосовуватись щодо всіх дітей з обмеженими можливостями, і тому за компетентними органами варто залишити широку можливість ухвалення рішень щодо оптимального використання ресурсів, виділених їм для забезпечення інтересів дітей з обмеженими можливостями загалом. 
Щодо осіб, які мають вади зору, у справі “С̧ат v. Turkey” ЄСПЛ зазначив: «<... Відмова прийняти до консерваторії незрячу особу, яка успішно пройшла вступний конкурс, становила порушення ст. 14 у сукупності зі ст. 2 Протоколу № 1. Компетентні державні органи жодним чином не намагались встановити потреби заявниці і не вказали, яким чином її неповносправність може становити перешкоду для музичної освіти. Вони також не намагались запровадити особливі пристосування, щоби задовольнити педагогічні потреби, які могла спричинити неповносправність заявниці» [12].

У цій справі ЄСПЛ вкотре звертає увагу на те, що «<...> Суд не знає, які особливі потреби кожної дитини, і це стосується особливо дітей з обмеженими можливостями. В освітній сфері Суд визнає розумним різноманітні форми організації навчання, що стосуються самої освіти та з погляду архітектури (доступність шкільних будівель), підготовку вчителів, адаптацію до навчальних програм <...> не $\epsilon$ завданням суду визначати ресурси, які будуть задіяні для дітей з особливими потребами, <...> Національна влада краще, ніж міжнародний суд має оцінювати потреби осіб з обмеженими можливостями <...>» (п. п. 66-67, “С̧ат v. Turkey").

У справі "Sanlisoy v. Turkey" заявник скаржився на те, що зазнав дискримінаційного порушення свого права на освіту через аутизм. ЄСПЛ вирішив, що «<...> у даному разі не встановлено систематичне нехтування правом заявника на освіту через аутизм або недотримання державою своїх зобов'язань за ст. 2 Протоколу № 1 у сукупності зі ст. 14 Конвенції» [13].

Отже, варто зазначити, що ЄСПЛ неодноразово відзначав важливість основоположних принципів та недопущення дискримінації в реалізації права на освіту. У справах "Çam v. Turkey" (§ 64) та "Sanlısoy v. Turkey” (§ 59) підкреслено, що інклюзивна освіта визнана найвідповіднішим засобом для гарантування прав людини.

Різницю у ставленні до доступу до освіти в розрізі наявності громадянства не можна виправдати в суспільстві. ЄСПЛ звертає увагу на те, що «<... тільки дуже вагомі міркування можуть змусити Суд уважати сумісною з Конвенцією різницею у ставленні, засновану виключно на громадянстві, адже право на освіту безпосередньо захищене Конвенцією і стосується громадської послуги особливого характеру, яка служить добробуту не лише осіб, які нею користуються, але й усього суспільства, a іiі демократичний вимір стосується інтеграції меншин» (“Ponomaryovi v. Bulgaria”) [14].
Ще однією категорією справ ЄСПЛ $є$ справи, які пов'язані з навчанням дітей ромського походження (етнічне походженням). В Україні питання навчання дітей ромів $\epsilon$ болючим через мінливість їхнього життя і постійну відірваність від суспільства. Роми становлять особливу меншину, яка перебуває в несприятливому й уразливому становищі, а тому вони потребують особливого захисту, який поширюється також і на освітню галузь. Саме тому національним судам треба ретельно розглядати справи такої категорії і застосовувати рішення ЄСПЛ.

Уразливе становище дітей ромів підтвердив і ЄСПЛ: «<...> Через таку уразливість держави мають застосовувати до них диференційоване ставлення, приділяти особливу увагу їхнім потребам, а відповідні державні органи мають сприяти вступу до школи дітей ромського походження навіть у випадках, коли відсутні необхідні адміністративні документи" ("Sampanis and others v. Greece”, § 86) [15].

Dfhnj зазначити, що в Європі існує традиція необґрунтованого зарахування дітей ромського походження до спеціалізованих класів ("Horvath and Kiss v. Hungary”, § 115) [16]. Не можна відокремлювати дітей, які не володіють на достатньому рівні мовою або іншими навичками для навчання, від однолітків, держави мають працювати над тим, щоб забезпечити оптимальний підхід до таких особливих дітей.

Варто звернути увагу й на те, що Європейський суд з прав людини для тлумачення понять, які містить ст. 2 Протоколу № 1, у своїй практиці неодноразово спирався на міжнародно-правові документи, серед яких:

- Загальна декларація прав людини (1948р.);

- Конвенція про боротьбу з дискримінацією в галузі освіти (1960р.);

- Міжнародний пакт про економічні, соціальні і культурні права (1966 р.);

- Міжнародна конвенція про ліквідацію всіх форм расової дискримінації (1966р.);

- Конвенція про права дитини (1989 р.) (“Catan and Others v. Republic of Moldova and Russia", п. п. 77-81);

- Конвенція про визнання кваліфікації з вищої освіти в європейському регіоні ("Leyla Şahin v. Turkey", п. 66);

- Конвенція ООН про права дитини (1989р.);

- Європейська соціальна хартія (переглянута) ("Ponomaryovi v. Bulgaria");

Конвенція про права осіб з інвалідністю (“Çam v. Turkey”, п. 65). 
Висновки. Національним судам під час розгляду справ, пов'язаних із порушенням права на освіту, варто враховувати розвиток міжнародного і європейського права за допомогою досягнення консенсусу в питаннях мови, освіти, навчання, які демонструє Європейський суд з прав людини. Варто звертати увагу на те, що Суд у тлумаченні загальних норм права неодноразово спирався на міжнародно-правові документи, які стосуються прав національних меншин, прав дитини, а також прав осіб з інвалідністю, використовувати ці міжнародні документи у зв'язку із сучасною ситуацією, що склалася в Україні.

\section{Література}

1. Конституція України 1996 р. URL: https:// zakon.rada.gov.ua/laws/show / 254\%D0\%BA/ 96 \%D0\%B2\%D1\%80\#Text.

2. Рішення Конституційного Суду України від 21 листопада 2002 р. № 18-рп/2002. URL: https:// zakon.rada.gov.ua/laws/show/v018p710-02\#Text.

3. Рішення Конституційного Суду України від 12 квітня 2012 р. № 9-рп/2012. URL: https://zakon. rada.gov.ua/laws/show/v009p710-12\#Text.

4. Протокол № 1 до Конвенції про захист прав людини і основоположних свобод. URL: https:// zakon.rada.gov.ua/laws/show/994_535\#Text.

5. Affaire "relative à certains aspects du régime linguistique de l'enseignement en Belgique" c. Belgique, 23 липня 1968 p. URL: https://hudoc.echr. coe.int/eng\#\{\%22itemid\%22:[\%22001-62083\%22]\}.

6. Рішення у справі “Campbell and Cosans v. The United Kingdom" від 25 лютого 1982 р. URL: https: / / hudoc.echr.coe.int/eng\#\{\%22itemid\%22: [\%22001-57455\%22]\}.

7. Рішення у справі “Sulak v. Turkey” від 17 січня 1996 p. URL: https://hudoc.echr.coe.int/eng\#\{\%22ite mid\%22:[\%22001-2669\%22]\}.
8. Рішення у справі “Cyprus v. Turkey” від 10 травня 2001 p. URL: https: / /hudoc.echr.coe.int/eng\#\{\%22i temid\%22:[\%22001-59454\%22]\}.

9. Рішення у справі “Leyla Șahin v. Turkey". URL: https://hudoc.echr.coe.int/eng\#\{\%22itemid\%22: [\%22001-70956\%22]\}.

10. Рішення у справі “Mürsel Eren v. Turkey" від 3 червня 2006 p. URL: https:/ / hudoc.echr.coe.int/eng \#\{\%22itemid\%22:[\%22001-72293\%22]\}.

11. Рішення у справі "Catan and Others v. Republic of Moldova and Russia" від 19 жовтня 2012 p. URL: https://hudoc.echr.coe.int/eng\#\{\%22ite mid\%22:[\%22001-114082\%22]\}.

12. Рішення у справі “Çam v. Turkey” від 23 лютоro 2016 p. URL: https://www.legislationline.org/ download/id/7067/file/ECHR_Cam_v_Turkey_2016_ en.pdf.

13. Рішення у справі "Sanlısoy v. Turkey" від 8 листопада 2016 p. URL: https://www.ethos-europe. eu/sites/default/files/tu_right_to_education.pdf.

14. Рішення у справі "Ponomaryovi v. Bulgaria” від 21 червня 2011 p. URL: https://hudoc.echr.coe.int/ eng\#\{\%22itemid\%22:[\%22001-105295\%22]\}.

15. Рішення у справі "Sampanis and others $v$. Greece" від 5 вересня 2008 р. URL: https://hudoc. echr.coe.int/eng\#\{\%22itemid\%22:[\%22001-86798\%22]\}.

16. Рішення у справі "Horvath and Kiss v. Hungary" від 23 січня 2013 p. URL: https://www. equal rightstrust.org/ertdocumentbank/Case $\% 20$ Summary\%20Horvath\%20v\%20Hungary.pdf.

Біла-Кисельова А. А., кандидат юридичних наук, сертифікований тренер Національної школи суддів України, суддя

Білозерського районного суду Херсонської області 